$$
\text { ilmiyat }
$$

Tokat IImiyat Dergisi | Tokat Journal of IImiyat

9/1 (Haziran | June 2021)

ISSN 2717-6134 | e-ISSN 2717-610X

\title{
Din Öğretiminin Amaçları Bağlamında Kültürel Aidiyet ve Kültüirel Sorumluluk Bilinci
}

\author{
Awareness of Cultural Belonging and Cultural Responsibility in the \\ Context of the Aims of Religious Education
}

\author{
Yasin Yičit \\ Dr. Öğr. Üyesi, Iğdır Üniversitesi Asst. Prof., Iğdır University \\ Illahiyat Fakültesi Faculty of Theology \\ Din Eğitimi Ana Bilim Dalı Department of Religious Education \\ Iğdır|Türkiye Iğdır|Turkey \\ yasnyigit@gmail.com orcid.org/0000-0002-3254-5350 \\ Makale Bilgisi | Article Information \\ Makale Türü| Araştırma Makalesi Article Types | Research Article \\ Geliş Tarihi | 17 Ocak 2021 Received | 17 January 2021 \\ Kabul Tarihi | 04 Mayıs 2021 Accepted | 04 May 2021 \\ Yayın Tarihi | 30 Haziran 2021 Published | 30 June 2021
}

\section{Atıf | Cite as:}

Yiğit, Yasin. “Din Öğretiminin Amaçları Bağlamında Kültürel Aidiyet ve Kültürel Sorumluluk Bilinci [Awareness of Cultural Belonging and Cultural Responsibility in the Context of the Aims of Religious Education]". Tokat IImiyat Dergisi | Tokat Journal of Ilmiyat 9/1 (Haziran | June 2021), 323-346.

https://doi.org/10.51450/ilmiyat.863033

\section{intihal | Plagiarism}

Bu makale, iTenticate aracılığıyla taranmış ve intihal içermediği teyit edilmiştir. | This article, has been scanned by iThenticate and no plagiarism has been detected.

\section{Copyright $\odot$}

Published by Tokat Gaziosmanpaşa University Faculty of Islamic Sciences. Tokat | Turkey. https://dergipark.org.tr/ilmiyat 


\section{Awareness of Cultural Belonging and Cultural Responsibility in the Context of the Aims of Religious Education}

Abstract: With the development of technology in today's societies, communication opportunities increase and all people in the world are getting closer to each other. This situation brings about social and cultural changes and many innovations. Considering the positive side of this process, which is called globalization, it can be thought that it is in the benefit of humanity as it enables us to get to know each other and benefit from each other's cultural richness of different societies. However, as a result of globalization, some cultures impose their own cultures on other societies by coming forward with the effect of their technological appeal. This brings about the threat of cultural alienation and cultural degeneration.

Struggling the threat of cultural alienation and cultural degeneration can be evaluated as a national, spiritual and humanitarian duty that must be fulfilled as a nation. In order for this task to be fulfilled out successfully, it is necessary to be worked for the new generation to gain cultural competence. Cultural competence can be expressed as having the necessary knowledge and skills to recognize, adapt, protect and develop the self-culture of the society in which the individual lives. It's used from the educational activities for the individuals of the society to acquire this knowledge and skills.

Emphasizing the emergence of the threat of cultural degeneration and alienation in this research, it is aimed to attract attention to the importance of raising with consciousness of cultural belonging and cultural responsibility of young generations through religious education. The study was designed according to the grounded theory, which is one of the qualitative research designs. The main problem of the research is which aims should be adopted gradually in religious education in order to struggle with cultural alienation and cultural degeneration.

According to the research, it can be effectively struggled with the threat of cultural alienation and cultural degeneration through religious education. As a matter of fact, the religion that directs the attitudes and behaviors of individuals with the values it reveals has the potential to become the source, essence and ferment of culture. In addition, religion has the potential to prevent or slow if cultural change is in a negative direction, to encourage it if it is in a positive direction.

A rich cultural heritage has been revealed in the past of Turkish society. Cultural alienation and cultural degeneration that occurs due to the fact that this heritage is not transferred on to the new generations with the right methods can be evaluated as a cultural slaughter. The interaction between religion and culture requires that religious education be made functional in resolving the issue. In this context, it was emphasized in the research that it should be aimed for individuals to gain awareness of first cultural belonging (recognizing culture and adopting culture) and then cultural responsibility (preserving culture, developing culture) in religious education. In this way, it is expressed that cultural alienation and corruption can be prevented. It is thought that the research is important since it raises awareness about the education of individuals who contribute to cultural development by attracting attention to the threat of cultural alienation and corruption.

Keywords: Religious Education, Culture, Cultural Competence, Cultural Belonging, Cultural Responsibility. 


\section{Din Öğretiminin Amaçları Bağlamında Kültürel Aidiyet ve Kültürel Sorumluluk Bilinci}

Öz: Günümüz toplumlarında teknolojinin gelişmesiyle birlikte haberleşme imkânları da artmakta, dünyadaki tüm insanlar birbirine yakınlaşmaktadır. Bu durum sosyal ve kültürel anlamda değişimi ve birçok yeniliği beraberinde getirmektedir. Küreselleşme adı verilen bu sürecin olumlu tarafından bakıldığında farklı toplumların birbirini tanımasına ve birbirlerinin kültürel zenginliklerinden faydalanmasına vesile olmasından dolayı insanlığın yararına olduğu düşünülebilir. Ancak küreselleşme neticesinde teknolojik cazibelerinin de etkisiyle bazı kültürler öne çıkarak diğer toplumlara kendi kültürlerini dayatmaktadır. Bu da kültürel yabancılaşma ve kültürel yozlaşma tehdidini beraberinde getirmektedir.

Kültürel yabancilaşma ve kültürel yozlaşma tehdidiyle mücadele etmek, millet olarak yerine getirilmesi gereken millî, manevî ve insanî bir görev olarak değerlendirilebilir. Bu görevin başarılı bir şekilde yerine getirilmesi için yeni neslin kültürel yetkinlik kazanması gerekir. Kültürel yetkinlik, bireyin yaşadığı toplumun öz kültürünü tanıma, benimseme, koruma ve geliştirme konusunda gerekli bilgi ve becerilere sahip olması şeklinde tanımlanabilir. Toplumun bireylerinin bu bilgi ve becerileri kazanması için eğitim faaliyetlerinden faydalanılır.

Bu araştırmada kültürel yozlaşma ve yabancılaşma tehdidinin ortaya çıkması vurgulanarak, din öğretimi aracılığıyla genç kuşakların kültürel aidiyet ve kültürel sorumluluk bilinciyle yetiştirilmesinin önemine dikkat çekmek amaçlanmıştır. Çalışma nitel araştırma desenlerinden biri olan gömülü teoriye göre tasarlanmıştır. Araştırmanın temel problemi kültürel yabancılaşma ve kültürel yozlaşmayla mücadele etmek için din öğretiminde aşamalı olarak hangi amaçların benimsenmesi gerektiğidir.

Araştırmaya göre din eğitimi aracılığıyla kültürel yabancılaşma ve kültürel yozlaşma tehdidiyle etkin bir şekilde mücadele edilebilir. Nitekim ortaya koyduğu değerlerle bireylerin tutum ve davranışlarını yönlendiren din, kültürün kaynă̆ı, özü ve mayası haline gelme potansiyeline sahiptir. Ayrıca dinin kültürel değişim olumsuz yöndeyse engelleme ya da yavaşlatma, olumlu yöndeyse teşvik etme potansiyeli bulunmaktadir.

Türk toplumunun geçmişinde zengin bir kültürel miras ortaya konulmuştur. Bu mirasın yeni nesillere doğru yöntemlerle aktarılmaması dolayısıyla meydana gelen kültürel yabancılaşma ve kültürel yozlaşma bir kültür kıyımı olarak değerlendirilebilir. Din ve kültür arasındaki etkileşim, meselenin çözümü hususunda din eğitiminin işlevsel hale getirilmesini gerektirir. Bu bağlamda araștırmada din eğitiminde bireylerin önce kültürel aidiyet (kültürü tanıma, benimseme), sonra kültürel sorumluluk (kültürü koruma, kültürü geliștirme) bilinci kazanmasının amaçlanması gerektiği vurgulanmıștır. Böylece kültürel yabancılașma ve yozlașmanın önüne geçilebileceği ifade edilmiștir. Araștırmanın kültürel yabancılașma ve yozlașma tehdidine dikkat çekerek kültürel gelişime katkı sağlayan bireylerin yetiştirilmesi hususunda farkındalığı artırdığı için önemli olduğu düşünülmektedir.

Anahtar Kelimeler: Din Eğitimi, Kültür, Kültürel Yetkinlik, Kültürel Aidiyet, Kültürel Sorumluluk. 


\section{Giriş}

Toplumsal bir varlık olarak dünyaya gelen insanoğlunun yaşamın-

da eğitim, olmazsa olmaz bir gereksinimdir. Zira her toplum için büyük bir önem taşıyan eğitim, toplumun edindiği tecrübelerini sonraki nesillere aktarmasını, yeni kuşakların toplumsallaşmasını, yaşadıkları toplumun değerlerini benimsemesini sağlayan bir kültürleme süreci olarak işlev görmektedir. ${ }^{1} \mathrm{Bu}$ bağlamda bir toplumda var olan eğitimin niteliğinin, o toplumun geleceğine ayna tuttuğu söylenebilir. Nitekim Topçu'nun deyimiyle "Bir neslin kurtuluşunu ancak maarifinin yükselmesinde aramak lâzımdır." $\mathrm{Bu}$ nedenle eğitim alanında sürekli ve nitelikli araştırmaların yapılması, bu çalışmalardan faydalanılarak öğretim sürecinde benimsenen yaklaşımların, hedeflerin ve amaçlara ulaşılması için yürütülen faaliyetlerin -çağın beklentilerine karşılık verebilecek bilgi ve becerilerle donanmaya muhtaç olan- günümüz insanını yetiştirmek için zaman zaman güncellenmesi önem arz etmektedir.

Günümüzde dünya küreselleşme adı verilen önce ekonomik hayatta baş gösteren, daha sonra kültürel sahada büyük yankılar uyandıran ve sonuçta gündemde küresel kültürel sistem şeklinde ifadesini bulan dinamik bir oluşum ve sürecin ${ }^{3}$ etkisi altında bulunmaktadır. Bu süreçte dünya adeta küçülmekte, herhangi bir yerde meydana gelen bir olay kısa sürede çok uzaklardaki insanlar tarafından da hissedilebilmektedir. Kısacası artık hiçbir ülkenin yaşamı diğerlerinden tamamen ayrılmış ve bağımsız değildir. ${ }^{4} \mathrm{Bu}$ durum sosyal hayatı derinden etkilemekte, toplumsal anlamda hızlı değişimlerin yaşanmasına neden olabilmektedir. Buna paralel olarak ortaya çıkan bireysel ve toplumsal sorunlardan dolayı günümüzde insan ve toplum üzerine yapılan bilimsel araştırmaların sayısı gün geçtikçe hızla artmaktadır. ${ }^{5}$

Dünya çapında meydana gelen sosyal ve kültürel değişimlerin Türk toplumunu da kıskacı altına aldığı, toplumdaki yerleşik kurumlaşmış din, gelenek haline gelmiş dinî kültür, değerler ve yaşantı alanında derin izler bıraktığı görülmektedir. ${ }^{6}$ Nitekim internet, TV ve diğer kitle iletişim araçları aracilığıyla çağımızda çeşitli yaşam felsefeleri ve kültürel unsurlar dünya çapında serbest ve hızlı bir şekilde yayılmaktadır. Bu durumun

\footnotetext{
Mark E. Mendenhall vd., Global Management (Oxford, UK: Blackwell Pub., 1995), 92. Nurettin Topçu, Türkiye'nin Maarif Davasl (İstanbul: Dergah Yayınları, 2012), 29.

Ünver Günay, “Çağdaş Türkiye'de Din, Toplum, Kültür, Gelenek ve Değişme”, Çukurova Üniversitesi İlahiyat Fakültesi Dergisi 1/2 (Haziran 2001), 2.

4 Anthony Giddens, Modernliğin Sonuçları, çev. Ersin Kuşdil (İstanbul: Ayrıntı Yayınları, 1998), 66-69.

5 Murat Tuncer vd., "Sosyal Araștırmalardaki Ölçek Bulgularına Örneklem Etkisinin Araștırılmas1", Electronic Journal of Education Sciences 6/11 (2017), 2.

6 Günay, “Çağdaş Türkiye'de Din, Toplum, Kültür, Gelenek ve Değişme”, 3-4.
} 
olumlu etkilerinin yanı sıra literatürde kültürel yabancılaşma ve kültürel yozlaşma kavramlarıyla ifade edilen bir tehlike dolayısıyla milletlerin öz kültürlerine yıkıcı bir darbe vurabileceği gözden kaçırılmamalıdır. Bu nedenle söz konusu değişimin gerek olumlu gerek olumsuz yönlerinin millî eğitimin kültürel amaçları bağlamında bilimsel olarak ele alınması, bu çalışmalardan faydalanılarak eğitim alanında gerekli yapılandırmaların gerçekleştirilmesi hayatî bir önem taşımaktadır.

1739 sayılı Milli Eğitim Temel Kanunu'nda “Türk Milletinin milli, ahlaki, insani, manevi ve kültürel değerlerini benimseyen, koruyan ve geliştiren yurttaşlar yetiştirmek." Milli Eğitim'in genel amacı olarak ifade edilmektedir.7 Kanunun bu maddesinden Türkiye'de toplumsallaştırma ve kültürlemenin eğitimin önemli bir amacı olarak kabul edildiği anlaşılmaktadır. Ancak eğitim imkânlarından yararlanma oranlarının giderek artmasına rağmen genç neslin önemli bir kısmının kültürel değerlere duyarsızlaştı̆̆ı, yani kültürel yabancılaşmanın ve yozlaşmanın baş gösterdiği gözlenmektedir. ${ }^{8}$ Bu durumun olumsuz etkilerinin asgari seviyeye çekilmesi için yeni kuşaklar tarafından millî tarihimizin bilinmesi, öz kültürümüzün içselleştirilmesi, millî ve dinî duyguların canlı tutulması oldukça önem arz etmektedir. Nitekim toplumsal olarak ilelebet varlığ1mızı devam ettirmenin önemli bir gereksinimi, özümüze uymayan çeşitli kültürleri taklit etmek yerine kendi değerlerimizi öz kültürümüze uygun bir şekilde modern hayata uyarlamak, böylece geçmişten geleceğe uyumlu bir geçiş sağlayabilmektir.

Günümüz şartları toplumu meydana getiren her bireyin öz kültürünü ileri seviyeye taşıyacak becerileri edinmesini, yani kültürel yetkinliğe sahip olmasını zorunlu kılmaktadır. Bunun için bireylerin yaşadıkları toplumun kültürünü tanımaları ve bu kültürü benimsemeleri, yani kültürel aidiyet bilinci kazanmaları gerekmektedir. Ancak kültürel yetkinliğe sahip olmak sadece mevcut kültürü tanıyı benimsemekle mümkün olamaz. Zira bu kültürü bozucu cereyanların etkisinden korumak ve geliştirmek, yani kültürel sorumluluk almak kültürel yetkinlik kazanmanın önemli bir şartıdır. Bu yetkinliğin bireylere kazandırılmasında din öğretiminin önemli bir rolü bulunmaktadır. Nitekim her toplumda kaçınılmaz olarak din ve kültür arasında bir etkileşim bulunmaktadır. ${ }^{9}$ Bundan ötürü bilim-

Milli Eğitim Temel Kanunu (METK), Resmî Gazete 14574 (24 Haziran 1973), Kanun No. 1739, md. 2/1; MEB, Din Kültürü ve Ahlak Bilgisi Dersi Öğretim Programı (İlkokul 4 ve Ortaokul 5, 6, 7 ve 8. Sinıflar) (Ankara: MEB Yayınları, 2018), 1.

8 Ramazan Bulut, “Okulda Din Öğretiminin Toplumsal Temeli ve İşlevleri”, Sosyal Bilimler Dergisi 7/1 (2011), 33-34; Ejder Çelik - Emine Babaoğlan, "Üniversite Öğrencilerinin Yabancılașma Düzeyi”, Ahi Evran Üniversitesi Kırşehir Eğitim Fakültesi Dergisi 18/1 (Nisan 2017), 422.

Ejder Okumuş, “Toplum Bağlamında Din-Kültür Etkileşimi”, Electronic Turkish Studies 11/7 
sel bir temel üzerine oturtularak alanında uzman kişiler tarafindan yürütülen bir din öğretiminin genel eğitimin kültürel amaçlarına ulaşılması için yapıcı katkıları olacaktır. Buna karşın kültür konusunda yapılan araştırmaların daha çok sosyoloji, din sosyolojisi gibi alanlarda yoğunlaştığ1, örgün öğretimde okutulan derslerden birinin adının Din Kültürü ve Ahlak Bilgisi (DKAB) olmasına rağmen din eğitimi alanında öğrencilere kültürel aidiyet ve kültürel sorumluluk bilincinin kazandırılmasıyla ilgili yeterli sayıda ve nitelikte müstakil çalışmanın bulunmadığı görülmektedir.

Konuyla ilgili literatürde bulunan eserlere bakıldığında bunlardan biri olan "Din Öğretiminde Kültürel Aidiyet ve Sorumluluk Bilinci Kazanma Amacına Erişim Düzeyi Ölçeği: Geçerlik Güvenilirlik Çalışması” adlı makalede Yiğit ve Koca tarafindan konuyla ilgili bir ölçek geliştirilmiştir. ${ }^{10}$ “Teorik ve Pratik Açmazlarıyla Kültürel Miras Öğretimini Sorgulayan Bir Deneme" adlı makalede Selçuk tarafından kültürel miras öğretimi ve din eğitimi üzerine değerlendirmeler yapılmıştır." "Kültürel Din Pedagojisi" adlı çalışmada Okumuşlar ve Bilecik tarafından kültürel din pedagojisi kavramı tanıtılarak kültür ve din pedagojisi arasındaki ilişkiden hareketle Türkiye'de daha etkili bir din öğretiminin oluşturulmasına katkı sağlanmak amaçlanmıştır. "12 “Türkiye'nin Maarif Dâvası” adlı kitaptaysa Topçu, eğitim alanındaki bozulmaya dikkat çekerek yozlaşmanın önlenmesi için millî mekteplerin kurulması gerektiğini ifade etmiştir. ${ }^{13}$ Ancak günümüzde baş gösteren yozlaşma ve yabancılaşma sorunları bağlamında din öğretiminin kültürel amaçlarını bütüncül bir bakış açısıyla yeterli oranda ele alan bir çalışmayla karşılaşılmamıştır.

Bu araştırmanın temel problemi kültürel yabancılaşma ve yozlaşmayla mücadele edilmesi için din öğretiminde aşamalı olarak hangi amaçların benimsenmesi gerektiğidir. Çalışma nitel araştırma desenlerinden biri olan gömülü teoriye göre tasarlanmıştır. Bu desende var olan teoriyi ortaya çıkarmak veya mevcut teorinin gelişmesine katkı sağlamak amaçlanır. ${ }^{14}$ Çalışmada günümüzde farklı kültürlere açılımın kolaylaşması dolayısıyla kültürel yozlaşma tehdidinin baş göstermesine vurgu yapılarak din öğretimi aracılığıyla geleceğin teminatı olan genç kuşakların kültürel aidiyet

(2016), 290.

${ }^{10}$ Yasin Yiğit - Hüseyin Kasım Koca, "Din Öğretiminde Kültürel Aidiyet ve Sorumluluk Bilinci Kazanma Amacına Erişim Düzeyi Ölçeği: Geçerlik Güvenilirlik Çalışması”, Bingöl Üniversitesi İlahiyat Fakültesi Dergisi 14 (Aralık 2019), 112.

${ }^{11}$ Mualla Selçuk, "Teorik ve Pratik Açmazlarıyla Kültürel Miras Öğretimini Sorgulayan Bir Deneme", Ankara Üniversitesi İlahiyat Fakültesi Dergisi 39/2 (1999), 258.

${ }^{12}$ Muhiddin Okumuşlar - Sümeyra Bilecik, "Kültürel Din Pedagojisi", Cumhuriyet İlahiyat Dergisi 23/3 (Aralik 2019), 1281-1283.

${ }^{13}$ Topçu, Türkiye'nin Maarif Davası, 13-15.

${ }^{14}$ John W. Creswell, Araştırma Deseni: Nitel, Nicel ve Karma Yöntem Yaklaşımları, çev. ed. Selçuk Beşir Demir (Ankara: Eğiten Kitap Yayınları, 2017), 10. 
(kültürü tanıma ve benimseme) ve kültürel sorumluluk (kültürü koruma ve geliştirme) bilinciyle yetiştirilmesinin önemine dikkat çekmek amaçlanmıştır. Çalışmanın öz kültürün öğretimi konusunda araştırmacılara ışık tutacă̆ı, böylece din öğretimiyle ilgili yaklaşımlar güncellenirken dikkate alınacağı düşünülmektedir.

\section{Dinin Kültürr Üzerindeki Etkisi}

Kültür, farklı bilimlerin ilgi alanına giren bir terim olduğu için literatürde birçok kültür tanımılla karşılaşılabilmektedir. Söz konusu tanımlarda genel kabul olarak kültürün insanoğlu tarafından beşeri, estetik, bilimsel, maddî ve biyolojik alanlardaki üretilen her türlü birikim şeklinde anlaşıldı̆̆ı görülmektedir. ${ }^{15}$ Ancak bu tanımların önemli bir kısmında kültür, sadece somut olana indirgenmiştir. Oysaki kültürün manevî boyutu da bulunmaktadır. Ünlü bir antropolog olan Edward Taylor'un kültürü yaşantı şekli, toplumun atalarından edindiği düşünüş, idealler, simgeler, davranışlar ve değerler gibi unsurları olan miras ${ }^{16}$ şeklinde tanımlaması kültürün maddî ve manevî olmak üzere iki veçhesinin bulunduğunu göstermektedir. Öte yandan maddî sahada üretilen birçok kültür öğesinde millî ya da manevî değerlerin izlerinin görülmesi de maddî kültürün manevî kültürden önemli derecede etkilendiği gerçeğini gözler önüne sermektedir. Öyleyse kültür, "Bir toplumun tarih boyunca ürettiği maddî ve manevî değerlerin, fikir ve sanat eserlerinin, bunlardan doğan değer yargılarının bütünü" ${ }^{17}$ şeklinde tanımlanabilir.

Geniş anlamıyla kültür, toplumun yaşam biçimi olarak görülebilir. Din de kutsalın yaşanmasıdır. ${ }^{18}$ Dolayısıyla din ve kültür arasında karşılıklı ve sıkı bir etkileşimden söz etmek mümkündür. Bu etkileşim bazen karşılıklı uyum, barış ve uzlaşı şeklinde; bazen de uyumsuzluk, düşmanlık ve çatışma şeklinde tezahür edebilmektedir. ${ }^{19}$ Bunda toplum tarafından kabul gören kültürün ve din(ler)in telkin ettiği yaşam tarzının birbiriyle uyumlu olup olmamasının etkisi büyüktür. Nitekim dinler anlam arayışında mensuplarına yol gösterir, onlarının hayatını düzenleyici birtakım kurallar, değerler belirler ve bunlara uyulmaması durumunda mensuplarına manevî yaptırımlar sunar.

${ }^{15}$ David Jary - Julia Jary, Dictionary of Sociology (Glasgow: Harper Collins Publishers, 1995), 139140.

${ }^{16}$ Edward B. Taylor, The Origins of Culture and Religion in Primitive Culture (New York: Harper\&Brothers., 1958), 269.

${ }^{17}$ Hüseyin Yılmaz, Din Eğitimi ve Sosyal Barış (İstanbul: İnsan Yayınları, 2003), 102-103.

18 Joachim Wach, Din Sosyolojisi, çev. Ünver Günay (İstanbul: Marmara Üniversitesi İlahiyat Fakültesi Vakfi Yayınları, 1995), 37.

19 Okumuş, “Toplum Bağlamında Din-Kültür Etkileşimi”, 272. 
Üyelerinin duygu, düşünce ve davranışlarını yönlendiren dinlerin kültür üzerinde doğrudan ya da dolaylı olarak tesiri bulunur. Bu durum birçok toplumda öyle boyutlara gelebilir ki din, kültürün ana kaynağı, mayası, özü haline dönüşebilir, ${ }^{20}$ mensuplarının aynı amaç doğrultusunda kenetlenmesini sağlayarak birlik, beraberlik, yardımlaşma ve dayanışma şuuruyla insanlık tarihinde çı̆̆ır açan bir medeniyetin kurulmasında ya da teşekkülünde öncü rol oynayabilir. Öte yandan bir toplumun ayakta kalmasında değerlerine bağlı kalmasının önemi büyüktür. Kök değerlerin yozlaşması ise o toplumun varlığını tehdit ederek yok olmasına neden olabilir. Bu durum düşünüldüğünde söz konusu değerlerin belirlenmesinde ve korunmasında mühim bir rolü bulunan dinin kültürel açıdan kıymetinin ne derece büyük olduğu anlaşılabilir.

Türkiye'deki duruma bakıldığında İslâm dininin hayatın önemli ve ayrılmaz bir parçası olduğu görülmektedir. ${ }^{21} \mathrm{Bu}$ din doğuşundan itibaren mensuplarının zihnine ve vicdanına tesir ederek tarihte Asr-ı Saadet şeklinde isimlendirilen ilâhi kaynaklı ender bir kültürün teşekkülüne vesile olmuştur. Öte yandan İslâm, bu mirası devralan sonraki nesillerin katkılarıyla güçlü bir medeniyetin kurulmasında lokomotif rolü üstlenmiştir. Bu medeniyet Türk-İslâm senteziyle zenginleşerek asırlarca Osmanlı bayrağ 1 altında dünyaya önder olmuştur.

\section{Din Öğretiminin Kültürel Amaçları}

Türkiye Türk-İslâm kültürünü temsil eden Osmanlı'dan bayrağı devralan, sosyal, hukuki ve demokratik bir devlettir. Türkiye'de gerek toplumun, gerekse de toplumu yöneten mercilerin atalarından teslim aldıkları hazine değerindeki kültür mirasını emanet bilinciyle elinde tutmak için gayret etmeleri hayati derecede önem arz etmektedir. Bu mirasin sadece maddî unsurlardan ibaret olmadığı ve manevî unsurların teşekkülünde toplum tarafından benimsenen din ve değerlerin tesiri bulunduğu için dünya görüşünün ve ahlak sisteminin belirlenmesinde ilâhi bilgi göz ardı edilmemelidir. Çünkü bu durum ahireti anlama hususunda yanılmaya yol açacağı gibi dünyayı anlamlandırmada da açmaza düşülmesine, dolayısıyla kültürün ve sosyal yapının bozulmasına neden olabilir. ${ }^{22}$

Türk toplumunun kültürel mirası, bünyesinde köklü değerleri ihtiva etmektedir. Bu mirasın sonraki kuşaklara aktarılması için millet olarak

${ }^{20}$ Suat Cebeci, "Milli Kimlik Bağlamında Din - Kültür İlişkisi”, Akademik İncelemeler Dergisi 3/2 (Ağustos 2014), 1; Okumuş, “Toplum Bağlamında Din-Kültür Etkileşimi”, 279.

${ }^{21}$ Ünver Günay, “íktisadi Ahlak ve Din”, Atatürk Üniversitesi İlahiyat Fakültesi Dergisi 7 (2006), 111.

${ }^{22}$ Tuncer Naml1, "Kuran ve Dünyevileşme ya da Bir Dünya Görüşü Kırılması”, Eskiyeni 13 (Haziran 2009), 48-49. 
çaba sarf edilmesi gerekmektedir. Bu sorumluluk başta aile ve eğitim kurumları tarafindan üstlenilmelidir. Ancak bu açıklamalardan İslâm dininin örgün öğretim kapsamında herkese zorunlu olarak benimsetilmesi gerektiği anlaşılmamalıdır. Zira böyle bir durumdan halkın bir bölümü rahatsız olabilir. ${ }^{23}$ Bundan ötürü din öğretimi sürecinde dinden öğrenme ${ }^{24}$ yaklaşımının da ifade ettiği gibi kişisel ve kültürel kimliğin inşasında, yani bireyin ve toplumun gelişiminde dinden faydalanılması gerektiği söylenebilir. Bu durum farklı dinlerin öğretimi açısından da aynıdır. Lâkin Türkiye'deki sosyal yapının bir gereği olarak hangisine ne oranda öncelik verileceğine özen gösterilmelidir. Nitekim “İslâm dininin, milletimizin ruh ve ahlak kaynağı olduğunu anlamakta güçlük çekilmez. Ona karşı açılan mücadele, millet varlığına çevrilmiş silahtır." ${ }^{25}$

Görüldüğü üzere temel amaç olarak toplumsallaştırma ve kültürlemenin benimsendiği eğitimde kültür kavramı kilit kavramlardan biri olarak karşımıza çıkmaktadır. Çünkü pedagojik yaklaşımlar belirlenirken ülkenin politik durumu, sosyal yapısı gibi faktörlerin yanı sıra kültürü de belirleyici bir rol oynamaktadır. Eğitim aracılığıyla din kültürünün bireylere aktarılması da din öğretimi olarak tanımlanabilir. Genel eğitimde pedagoji ve kültür ilişkisi dolayısıyla kültürel, kültürlerarası ya da çok kültürlü pedagojik yaklaşımlardan söz edilebileceğ ${ }^{26}$ gibi din öğretiminde de toplumun sosyokültürel ve dinî yapısı göz önünde bulundurularak çeşitli yaklaşımlar benimsenmektedir. Türkiye açısından düşünüldüğünde ülkede hem farklı dinlere mensup grupların hem de aynı dine mensup olmakla birlikte çeşitli unsurların etkisiyle birbirinden ayrışan grupların yer alması dolayısıyla kültürel ve çok kültürlü modelin birlikte benimsenmesi düşünülebilir. ${ }^{27}$ Ancak öz kültürün korunması, kültürel yozlaşma tehdidinin bertaraf edilmesi için amaçların belirlenmesinde kültürel modele ağırlık verilebilir. Böylece kültürel anlamda sağlam bir temel oluşturulduktan sonra diğer kültürlere açılarak, saygı ve hoşgörü temelinde farklı kültürlerin zenginliklerinden faydalanılarak insanî olana odaklanılabilir. Öte yandan toplumsal ve kültürel değişimin kaçınılmaz olmasından ötürü din öğretiminin kültürel amaçlarının zaman zaman güncellenmesi gerektiği söylenebilir.

Günümüz şartlarında din öğretiminde hangi kültürel amaçların be-

${ }^{23}$ Ramazan Diler, Gazetelerde Din Dersi Tartışmaları (Ankara: İlahiyat, 2020), 90-96.

${ }^{24}$ Kathleen Engebretson, "Learning about and learning from religion. The pedagogical theory of Michael Grimmitt", International Handbook of the Religious, Moral and Spiritual Dimensions in Education, ed. Marian de Souza vd. (Dordrecht: Springer, 2006), 667-678.

${ }^{25}$ Topçu, Türkiye'nin Maarif Davası, 36.

${ }^{26}$ Okumuşlar - Bilecik, "Kültürel Din Pedagojisi”, 1281.

${ }^{27}$ Okumuşlar - Bilecik, "Kültürel Din Pedagojisi”, 1290. 
nimsenmesi gerektiği meselesine gelince bu konuda birçok şey ifade edilebilir. Ancak araştırmanın kısıtlılığından dolayı çalışmada meselenin sadece ana başlıklarla ele alınması, bunlarla ilgili alt maddelerin zaman zaman çağın şartlarına uygun olacak şekilde güncellenmesi yerinde olacaktır. Bu bağlamda din öğretiminin kültürel amaçları, 1739 sayılı Milli Eğitim Temel Kanunu'nda yer alan eğitimin genel amaçları ve DKAB dersi öğretim programı birlikte değerlendirildiğinde kültürün tanıtılması, benimsetilmesi, korunması ve geliştirilmesi olmak üzere dört ana başlık altında ele alınabilir. ${ }^{28} \mathrm{Bu}$ başlıklardan ilk ikisi kültürel aidiyet, diğerleri kültürel sorumluluk başlıkları altında sınıflandırılabilir. Zira kültürel aidiyet, bireyin öz kültürünü tanıyarak içselleştirmesini, kültürel sorumluluksa bu kültürü koruması ve ileri seviyeye taşıması için çalışmasını ifade etmektedir. ${ }^{29}$

\subsection{Kültürel Aidiyet Bilinci}

Bir yere ya da gruba yoğun duygularla bağlı olmak, kendisini ona mensup hissetmek şeklinde anlaşılabilen aidiyet, bireyin en temel ihtiyaçlarından biridir. Öyle ki Maslow'un ihtiyaçlar hiyerarşisinde fizyolojik ve güvenlik ihtiyaçlardan sonra ait olma gereksinimi bulunmaktadır. ${ }^{30} \mathrm{Bu}$ nedenle hiyerarşinin alt basamaklarındaki gereksinimlerini karşılayabilen her birey doğal olarak bu ihtiyacını da karşılamak isteyecektir. Bu bağlamda bireyin kendisini ailesine, memleketine, vatanına, toplumuna ya da olumsuz anlamda düşünülecek olursa çeşitli ideolojik guruplara ait hissetmesi mümkündür. Öte yandan bireyin kendini gerçekleștirme sürecinde yaşadığı toplumda öteden beri yer eden kültüre aidiyet duygularıyla bağlanmasının da mühim bir gereklilik olduğundan bahsedilebilir. Ancak günümüzde özellikle değişime açık olunan gençlik döneminde birey, küreselleşmenin etkisiyle farklı kültürlerle etkileşimde bulunabilir. Bunun sonucunda farklı kültürlere sempati duyarak ve toplumun kültürünü beğenmeyerek yaşadı̆̆ı toplumun bir parçası olmaktan kaçınabilir, toplumuyla çatışabilir.

İdeal bir din öğretiminde bireyin kendini gerçekleştirmesine (kemale ermesine) ve donanımlı bir şekilde hayata hazırlanmasına katkı sunmak amaçlanır. Bu nedenle onun kültürel ihtiyaçları ve bu ihtiyaçlarını karşılamaya çalışırken karşılaşabileceği problemleri din öğretimi progra-

${ }^{28}$ METK, md. 2/1; MEB, Din Kültürü ve Ahlak Bilgisi Dersi Öğretim Programı (İlkokul 4 ve Ortaokul 5, 6, 7 ve 8. Siniflar), 8.

${ }^{29}$ Yiğit - Koca, "Din Öğretiminde Kültürel Aidiyet ve Sorumluluk Bilinci Kazanma Amacına Erişim Düzeyi Ölçeği”, 112-114.

30 Abraham Harold Maslow, Motivation and Personality (New York: Harper and Row, 1970), 35-47. 
minın hedef, içerik, süreç ve ölçme değerlendirme öğeleri geliştirilirken göz ardı edilemez. Bu, birey ve toplum için hayati bir gerekliliktir. Zira inanç ve değerlerin kültürün özüne sirayet etme potansiyeli bulunduğu için kültürel aidiyet bilincinin kazandırılmasında din öğretimi önemli bir role sahiptir.

Din öğretiminde öğrencilere kültürel aidiyet bilincinin kazandırılabilmesi, toplumun kültürünü onlara tanıtmak ve benimsetmek olmak üzere iki aşamada mümkün olacaktır.

\subsubsection{Kültürïi Tanıtma Amacı}

Toplum, salt maddî çıkar ve amaçlardan meydana gelen bir oluşum değildir. Zira toplum müşterek inançlar, manevî değerler ve kültür zemininde bir araya gelen insanların meydana getirdiği bir teşekküldür. $\mathrm{Bu}$ teşekkülün temelini atan değerlerin başındaysa din ve dine bağlı değerler sistemi gelmektedir. ${ }^{31}$ Türk toplumunun tarihine bakıldığında ecdadın farklı coğrafyalarda farklı kültürlerle etkileşime girdiği, karşılaştığı kültürlerde bulunan unsurları özüne uygun bir şekilde sentezleyerek asırlar boyunca köklü değerler ürettiği, böylece yeni kuşaklara değer yüklü zengin bir kültürel miras bıraktığı görülmektedir. Bu bağlamda özellikle İslâm kültürünün Türk toplumunun millî kültürü üzerinde parlak yansımalarının bulunduğu söylenebilir.

Günümüze bakıldığındaysa kişilerarası ilişkilerde sosyal ve ahlakî kurallardan uzaklaşılması, genel menfaat yerine bireysel çıkarların ön plana alınmaya başlanması, yavaş fakat sürekli bir şekilde gerçekleştiği iddia edilen ahlakî çöküntünün baş göstermesi gibi nedenlerden ötürü toplumda genel anlamda öz kültürlerine layıkıyla bağlı kalan bireylerin azald1ğ1 ifade edilebilir. ${ }^{32} \mathrm{Bu}$ durumun elbette pek çok nedeni bulunmaktadır. Ancak en önemli nedenlerden birisi onlara öz kültürün nitelikli olarak aktarılamaması olabilir. İște geçmişle gelecek arasında sağlıklı, uyumlu ve güçlü bir bağ kurabilen millî benliğini kaybetmeyen nesiller yetiștirilebilmesi maksadıyla din öğretiminde kültürel mirasın tanıtılması, İslâm medeniyetinin birikiminin yeni kuşakların gözleri önüne serilerek günümüzde yaşayan ecdadın torunları için ilham kaynağı olması elzemdir.

Kültürün tanıtılması, bireylere kültürel ve kültürlerarası yetkinlik kazandırılmasının ilk adımıdır. Öte yandan öz kültürün ve kök değerlerin muhtevasının doğru yöntemlerle genç nesle aktarılması kültürel yaban-

${ }^{31}$ Bulut, “Okulda Din Öğretiminin Toplumsal Temeli ve İşlevleri”, 27.

32 Özlem Uygur - Süleyman Doğan, "Ahlaki Çöküşe Bir Çözüm Önerisi Olarak Türk İslam Ahlakı", IX. Uluslararası Dİ Görevlileri Sempozyumu Bildirileri, ed. Mustafa Sürün (İstanbul: YECVA, 2019), 196; Topçu, Türkiye'nin Maarif Davası, 31. 
cılaşmayı engelleyebilir, ${ }^{33}$ evrensel ahlakî değerlere ulaşılması için katkı sağlayabilir. Nitekim bu amaca ulaşılması için öncelikli olarak toplum, kendi kültürünün kök değerlerini tanımalıdır. ${ }^{34}$ Öyleyse kültürün öğrencilere aktarılması sadece belli ders ya da konularda değil, öğretim faaliyetlerinin bütününde en temel amaç olarak kabul edilmeli ve bunun gereği yapılmalıdır. Bu amaçla okul çatısı altında toplumun kültürel kimliğinin tanıtılması için öğrencilerin meraklarının canlı tutulması sağlanmalı, bunun için çeşitli etkinliklere başvurulmalıdır.

Konuya din öğretimi açısından bakıldığında din ve kültür arasındaki güçlü bağlar dolayısıyla eğitimin bu boyutunda tanıtımı yapılacak muhtevanın oldukça zengin olduğu söylenebilir. Bu nedenle din öğretimi faaliyetleri yürütülürken müfredatta bulunan çeşitli konular aracılığıyla toplumun kültürel kimliğiyle bağlantı kurulabilir, kültürel mirasın özellikle manevî unsurları öğrencilere tanıtılabilir. Bununla birlikte din öğretiminde kültürel mirasın daha da zenginleștirilmesi amacıyla yer yer farklı kültürlerde emsal teşkil eden kültür örüntülerinin tanıtımı da yapilabilir.

\subsubsection{Kültürrü Benimsetme Amacı}

Eğitimin toplumsallaştırma ve kültürleme amacına erişilmesi bireye sadece yaşadığı toplumun kültürünün tanıtılmasılla mümkün değildir. Bunun yanı sıra millî ve manevî değerler, bireylerin sahiplenebileceği bir şekilde öğretilmeli, böylece toplumun onları içselleştirerek öz kültürüne bağlı kalması sağlanmalıdır. Nitekim bireyin yaşadığı sosyal çevreye uyumlu bir kişilik geliştirmesi için toplumsal normları öğrenmesi ve öz benliğine yerleștirmesi zorunludur. ${ }^{35}$ Ancak günümüz Türkiye'sinde yürütülen öğretim faaliyetlerinde bu amacın daha çok teoride, yani yazılı metinlerde kaldığı, pratiğe istenen oranda yansımadığı gözlenmektedir. Bu tezi destekleyen bir araştırmaya göre öğretmenlerin \%75 gibi yüksek bir oranı öğretim sürecinde toplumsallaştırma ve kültürleme görevlerini yeterince icra etmedikleri gibi böyle bir sorumluluklarının varlığından bile bihaberdir. $^{36}$

Meseleye din öğretimi açısından bakılacak olursa öğretim programlarında kültürel becerilerin kazandırılmasıyla ilgili gereken vurgu yapıldı̆̆ı

${ }^{33}$ Haci Ömer Özden, "Bir Ahlâk Problemi Olarak Yabancılaşma ve Yahya Kemal", ílahiyat Akademi 2/3 (Eylül 2016), 110.

${ }^{34}$ Uygur - Doğan, “Ahlaki Çöküşe Bir Çözüm Önerisi Olarak Türk İslam Ahlakı”, 195-196.

35 Zeki Arslantürk, “Sorumluluk Şuurunun Sosyo-Kültürel Arkaplanı”, Kur'an-ı Kerim'de Mes'ûliyet (Kaynağı, Sinırları, Sonuçları), ed. Bedreddin Çetiner (İstanbul, 2006), 329.

${ }^{36}$ Hasan Çelikkaya, "Öğretmenlerin Kültürleme ve Sosyalleştirme Etkileri Üzerine Bir Araştırma”, Marmara Üniversitesi Ĕ̆itim Bilimleri Dergisi 26/26 (2007), 27-28. 
görülmektedir. Ancak mevcut ders kitaplarının satırlarına göz gezdirildiğinde toplumu ayakta tutan, ahlakî bilinçlenmeyi sağlayan birtakım değerlere yer verildiği görülmekle birlikte bunların büyük oranda bilişsel düzeyde ele alındığı dikkatten kaçmamaktadır. Nitekim ders kitaplarının içeriği hazırlanırken benimsenen genel eğilim, ilgili değerin sözlük anlamı ve tanımının yapılması, akabinde birkaç ayet ya da hadisle İslâm dininin o değeri teşvik ettiğinin ifade edilmesi ve faydalarının kısaca dile getirilmesi şeklindedir. ${ }^{37}$ Konuyla ilgili yapılan bir araştırma DKAB derslerinde ahlakî değerlerle ilgili duyuşsal öğrenmelerin amaçlandığı kazanımların müfredatta yer alan toplam kazanımların sadece \%3 gibi çok az kısmını oluşturduğunu ortaya koymuştur. ${ }^{38}$ Böyle bir durumun değerlerin ne anlama geldiği bilinse de öğrencilerin karakterlerinde iz bırakmamasına, pratik hayatta bildikleriyle çelişen davranışlar sergilemelerine neden olabileceği gözden kaçırılmamalıdır.

Kültürel değerlerin benimsenmesinden yoksun olan bir öğretim, geleceğin teminatı olan gençlere karakter yerine sadece hüner verecektir. ${ }^{39}$ $\mathrm{Bu}$ da meslekî anlamda bir başarı sağlasa bile muhtemelen o mesleğin icra edilmesi sırasında etik kaygıların yeterince düşünülmemesine, mesleğin sadece gelir kapısı gibi görülmesine yol açacaktır. Öte yandan kültürel değerler özverili bir şekilde toplum yararına çalışmayı teşvik ederek toplumların gelişmesine katkı sağlamaktadır. Bu değerlerin aklın yanında kalbe de hitap ederek çağın insanının manevî anlamda ilerlemesine katkı sağlama potansiyeli bulunan dinden yararlanılarak bireylere aktarılmaması, sosyal hayatın barış, güven ve huzur ortamında sürdürülebilirliğini tehdit edebilir. Çünkü din, toplumun birlik ve beraberlik içerisinde kenetlenmesini telkin eden önemli bir vasıta olarak görülebilir.

Güçlü toplumların temelinde manevî birlik ruhu bulunmaktadır. Bu ruhun Türk toplumundaki karşılığının İslâm dini olduğu söylenebilir. Bu nedenle din öğretiminde toplumun teşekkülünde önemli bir rol icra eden İslâm'ın manevî bütünleşmenin korunup güçlendirilmesinde oynadığ 1 etkin rolden faydalanılmalıdır. ${ }^{40}$ Zira İslâm'ın yetiştirmek istediği ahlaklı, vatansever, toplum yararına çalışmaya istekli insan tipiyle Türk eğitim sisteminin amaçları arasında benzerlikler bulunmaktadır.

37 Sadullah Macit, Ortaokul ve Imam Hatip Ortaokulu Din Kültürü ve Ahlak Bilgisi Ders Kitabı 7 (Ankara: FCM Yayıncılık, 2020), 55-83; Veli Karataş (ed.), Ortaöğretim Din Kültürü ve Ahlak Bilgisi 9. Sinıf Ders Kitabı (Ankara: MEB Yayınlar1, 2019), 86-101; Suna Akkurt (ed.), Anadolu İmam Hatip Lisesi Temel Dini Bilgiler Ders Kitabı (Ankara: MEB Yayınları, 2019), 74-143.

38 İbrahim Turan, "Gençlik Döneminde Görülen Ahlaki Sorunlar Karşısında Din Kültürü ve Ahlak Bilgisi Dersinin Yeri”, Atatürk Üniversitesi İlahiyat Fakültesi Dergisi 40 (2013), 290.

39 Topçu, Türkiye’nin Maarif Davası, 43.

40 Bulut, "Okulda Din Öğretiminin Toplumsal Temeli ve İşlevleri”, 35. 
İslâm'a göre "Tedib edebin nefiste zaptedilmesi ve bizzat kişi tarafindan hazmedilmesidir." ${ }^{\prime 1}$ Din öğretiminde bu çizgi üzerinde Osmanlı ve öncesi dönemlerde tecrübe edildiği gibi İslâm'ın akılcı, hoşgörülü ve bilimi destekleyen anlayışı temelinde işlenen kök değerleri vasıtasıyla toplumdaki farklı grupların tamamına hitap edilebilir. Bu nedenle Türkİslâm kültürünün zengin mirasının unutulmaya terk edilmemesi, din öğretimi aracılığıyla gençliğin karakterine işlenmesi için çalışılmalıdır. Böylece bireyin kültürleme yoluyla toplumsallaşması sağlanarak güçlü bir toplumun tesis edilmesi için dinden faydalanılmalıdır.

\subsection{Kültü̈rel Sorumluluk Bilinci}

Sorumluluk, bireyin kendi eylemlerinin ve yetki alanına giren herhangi bir durumun farkında olması, hayat sürecinde yaptığı tercihlerinin sonuçlarını üstlenmesidir. ${ }^{42}$ Sosyal ve kültürel sorumluluksa kişinin yaşadığı toplumun menfaatlerini düşünerek toplum yararına gönüllü olarak çalışması ya da toplum tarafından benimsenen kültürün korunup geliştirilmesi için çaba göstermesi gerektiğinin bilincinde olması, bu konuda severek ve isteyerek görev alması şeklinde ifade edilebilir.

Bir toplumda yaşayan bireylerin sosyal ve kültürel sorumluluk bilinci kazanması, dünyaca önemsenen sosyal ve ekonomik kalkınma amacına erişilmesi için olmazsa olmaz şartlardan biri olarak görülebilir. ${ }^{43}$ Nitekim böyle toplumlarda bireysel çıarlardan ziyade toplumun menfaati ön planda tutulacak, ortaya çıkan sosyal sorunlar birlik beraberlik şuuruyla hareket edilerek daha kısa vadede çözüme kavuşturulabilecek, bu durum toplumun maddî ve manevî refah düzeyinin yükselmesi için önemli katkı sağlayacaktır. Bu nedenle birey ve toplumun ihtiyaç ve beklentilerinin gözetildiği eğitim kurumlarında bireylere sosyal ve kültürel sorumluluk şuurunun kazandırılması için gerekli yapılandırmaların sağlanması elzemdir.

Eğitimde bireylere sosyal ve kültürel sorumluluk bilincinin kazandırılması milletlerin geleceğinin teminatı olarak düşünülebilir. Zira bilgi toplumu olma yolunda önemli adımların atıldığ küreselleşme süreci dolayısıyla ortaya çıkan kültürlerarası rekabette başka kültürlerin hegemonyası altına girmeden, öz kültürüne bağlı olarak onurlu bir şekilde yaşanılabilmesi ancak toplumda kendi kültürel kimliğinin ve sorumluluklarının bi-

${ }^{41}$ Syed Muhammad Naquıb Al-Attas, “ílmin Yozlaşması ve Fikri Çözünme Meselesi”, çev. Bülent Nuri, Journal of Islamic Research 7/3-4 (1994), 218.

42 Yener Özen, Sorumluluk Eğitimi (Ankara: Vize Basın Yayın, 2015), 9.

${ }^{43}$ Mehmet Ali Çalgan, "İslâm'da Toplumsal Sorumluluk Şuuru ve Günümüzde Toplum İçin Önemi”, Pamukkale Üniversitesi İlahiyat Fakültesi Dergisi 3 (Mart 2015), 39. 


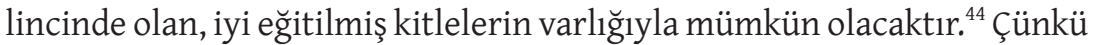
kültürel yabancılaşma ve yozlaşma tehdidiyle mücadele edebilecek güçlü bir toplumsal doku ancak bu sayede meydana getirilecektir.

Sosyal dokunun güçlendirilmesinde din, toplumu bir araya getirerek bireylerin yardımlaşma ve dayanışma içerisinde kenetlenmesini sağlayan bir çimento vazifesi görebilmektedir. Dinin, bireyin tutum ve davranışlarına olan tesiri ve dinle kültür arasındaki etkileşim düşünüldüğünde toplumda sosyal ve kültürel sorumluluğun kazandırılmasında din öğretimine önemli görevler düştüğü anlaşllabilmektedir. Çünkü sorumluluk bir değerdir ve halk kültüründe değerlerin kaynağı büyük oranda dinî inançlar olarak görülmektedir. Öte yandan dinî normlar kalıcı iken diğer toplumsal ve kültürel normlar daha çabuk değişebilir. ${ }^{45} \mathrm{Bu}$ durum toplumda köklü değerlerin yerleşmesi için dinî öğretilerden yararlanılması gerektiğini göstermektedir.

Bilindiği üzere Türk toplumunda kabul gören İslâm dininin önemli bir prensibi, bireysel ve toplumsal anlamda değerlendirilebilecek olan sorumluluk şuurudur. İslâm'ın bu öğretisinden faydalanılarak bireyin ilgisi topluma yönlendirilebilir. Böylece günümüz toplumlarında sıkça karşılaşılabilen bireyselliğin ve bencilliğin yaygınlaşması, yoksulluk, yolsuzluk, azgelişmişlik, zulüm, adaletsizlik, diyalog eksikliği gibi sosyal sorunlarla ${ }^{46}$ mücadele etme konusunda bilinçli bireyler yetiştirilmesi için din öğretimi etkin bir rol üstlenebilir. Öyleyse sosyal ve kültürel sorumluluk bilinci taşıyan, bunu benliğine yerleștirerek kalııı hale getiren, bu şuurla öz kültürün korunması ve geliştirilmesi için çaba sarf eden bireylerin yetiştirilmesi din öğretiminin en temel amaçlarından biri olmalıdır. Öte yandan bu amacın sadece teoride ve yazılı metinlerde kalmaması, yani pratiğe yansıması için çalışılması millı̂ bir görev olarak addedilmelidir.

\subsubsection{Kültürüi Koruma Bilinci Kazandırma Amacı}

Kültürün korunması ifadesiyle ne kastedildiğinin anlaşılabilmesi için öncelikle yabancılaşma ve yozlaşma kavramlarının ele alınması gerekmektedir. Sosyolojik birer terim olan bu kavramların ilk bakışta anlamca birbirine benzediği düşünülse de araştırıldığında birebir örtüşmedikleri anlaşılmaktadır. Toplumsal açıdan ele alınacak olursa yabancılaşma, bir toplumun kendine özgü yaşayış biçiminin, kültürel değerlerinin tedrici

\footnotetext{
${ }^{44}$ Erkan Perşembe, “Küreselleşme Kültürü ve Eğitimin İşlevi”, Ondokuz Mayıs Üniversitesi İlahiyat Fakültesi Dergisi 20/20-21 (Mart 2005), 101.

${ }^{45}$ Arslantürk, "Sorumluluk Şuurunun Sosyo-Kültürel Arkaplanı", 360.

${ }^{46}$ Çalgan, "İslâm'da Toplumsal Sorumluluk Şuuru ve Günümüzde Toplum İçin Önemi”, 27.
} 
olarak değişmesi sonucunda farklı bir yapıya bürünmesi demektir. ${ }^{47}$ Yozlaşmaysa bir toplumun tabiatındaki iyi özellikleri yitirmesi, manevî niteliklerinden uzaklaşması, özünü kaybetmesi, orijinalliğinin bozulması, dejenerasyon şeklinde anlaşılabilir. ${ }^{48} \mathrm{Bu}$ tanımlardan hareketle kültürü korumak, bir toplumun tarihsel süreçte kendisine has olarak ürettiği kültür örüntülerinin kültürel yabancılaşma ve yozlaşma tehlikelerine karşı muhafaza edilmesi şeklinde anlaşılabilir.

Kültürel yabancilaşma ve yozlaşma, her ne kadar hiçbir toplumun istemeyeceği bir durum olsa da küreselleşmeyle birlikte toplumların bu yıkıcı cereyanların ağına düşmesinin daha da kolaylaştığı söylenebilir. Küreselleşme sürecinde iletişim imkânlarına ulaşmanın kolaylaşmasıyla birlikte belki genel anlamda toplumların birbirini etkilediği ve birbirinden etkilendiği düşünülebilir. Ancak küreselleşmeyle birlikte bazı kültürlerin öne çıkarak hâkim kültür konumuna geldiği, diğer toplumlara kendi kültürünü bilinçli ya da bilinçsiz olarak dayattığı bilinmektedir. Bu bağlamda Batı toplumlarının ekonomik anlamdaki cazibesinin de etkisiyle dünyanın merkezi haline geldiği söylenebilir. ${ }^{49} \mathrm{Bu}$ bakımdan dünya çapında meydana gelen toplumsal hareketlilik incelendiğinde özellikle Amerikan kültürünün yaşamın çeşitli alanlarında kültürel hegemonyasını tesis ederek, küresel ölçekte kendisini evrensel kılma başarısını göstererek egemen kültür haline geldiği görülmektedir. ${ }^{50}$

Günümüzde Türk toplumunun yaşadığı tecrübelerden hareketle Batı'nın hâkim kültür olmasının geleneksel kültürler üzerinde olumsuz etkiler meydana getirdiği ifade edilebilir. Nitekim 19. yüzyıldan itibaren Batılı yaşam tarzına dair kodların Osmanlı toplumunda görülmesiyle birlikte ilerleyen süreçte bireyselleşme ve özgürleşme eğilimi baş göstermiştir. Bu eğilim, özgürlüğü engellediği ya da kısıtladığı düşünülen değerlerin sorgulanmasına yol açmış, bu nedenle örf, adet, gelenek, görenek, kültür ve kaynağını dinden alan toplumsal normlar tartışmaya açılmıştır. Bu durum toplumun kültürel değerlerinde Batılı yaşam tarzından etkilenilerek büyük çaplı değişiklikler meydana gelmesine neden olmuştur. ${ }^{51}$ Bütün bu olup bitenler modern toplumlarla beraber Batılılaşma adı altında Türkiye

47 Özden, "Bir Ahlâk Problemi Olarak Yabancilaşma ve Yahya Kemal”, 102.

${ }^{48}$ Güncel Türkçe Sözlük, "Yozlașma” (Erișim 10 Nisan 2020).

${ }^{49}$ Hassan Hanafi, "İslam ve Batılılaşma", çev. Yaşar Gedikli, On Dokuz Mayıs Üniversitesi İlahiyat Fakültesi Dergisi 10 (1998), 498.

50 İhsan Çapçıŏlu, "Küreselleşme, Kültür ve Din”, Ankara Üniversitesi İlahiyat Fakültesi Dergisi 49/2 (2008), 167.

${ }^{51}$ Geniş bilgi için bk. Jean M. Twenge, Ben Nesli, çev. Esra Öztürk (İstanbul: Kaknüs Yayın, 2013), 31-34. 
de dahil olmak üzere geleneksel toplumlarda da kültürel anlamda kitlesel bir değișime neden olmuştur. ${ }^{52}$

Günümüzde birçok toplumda Batılılaşma, modernlik ve çağdaşlaşmayla aynîleştirilmiş, bu yanlış algının etkisiyle Batılı yaşam tarzı kitle iletişim araçları, eğitim, kültür gibi bütün sosyal tabakalara nüfuz etmeye başlamıștır. Oysaki halk kültüründe ateizm, anarşizm, materyalizm, hegemonya, rrkçıllk, sömürge, kapitalizm ve anti-İslâm gibi anlamlara gelen Batılılaşma, çağdaşlaşmadan oldukça farklı ve kültürel yabancılaşma ve yozlaşmaya neden olabilen bir olgudur. ${ }^{53}$ Zira Batılllaşma, düşünce, davranış ve yaşantı şeklinde Avrupalılara benzeme; çağdaşlaşmaysa yaşanılan çağın icap ve şartlarına uyma, zamanın gereklerine göre hareket etme anlamına gelmektedir. Bu nedenle bilim ve teknolojide Batılılaşmal, Avrupa'ya uyulmalı, sosyal hayatta ve beșerî davranışlardaysa din ve ahlaka, geleneğe ve göreneğe tabi olunmalıdı. ${ }^{54}$ Aksi taktirde toplumda değişime açık olmaları dolayısıyla başta gençler olmak üzere kendi kültürüne yabancılaşan bireylerin yaygınlaşmasıyla birlikte toplumun varlığını tehdit eden toplumsal çözülme ve kültürel yozlaşma, telafisi mümkün olmayan boyutlara ulaşabilir ki bu durum bir kültür kıyımı olarak değerlendirilebilir.

Toplumda kültürel yabancılaşma ve yozlaşmanın baş göstermesine neden olan bir unsurun da medya olduğu söylenebilir. Nitekim medya, özellikle genç kuşağı kıskacı altına alarak toplumun kültürel değerlerden uzaklaşmasına sebep olabilmektedir. Buna göre medya, toplumun benimsediği geleneksel değerlerin çağ dışı olarak görülmesine neden olmakla birlikte film izlemek, bilgisayar oyunlarıly meşgul olmak, sosyal medyada vakit geçirmek gibi şeylere gereğinden fazla vakit ayrılmasına neden olabilmektedir. Bu durum toplumdaki bireylerin boş zamanlarını kültürel gelişime katkı sağlayacak şekilde değerlendirilmesine mâni olmaktadır. ${ }^{55}$ Bütün bu olup bitenlere eğitim kurumlarının göz yumması beklenemez. Zira toplumun bu husustaki cehaleti ve bilinçsizliği ancak nitelikli bir eğitimle ve ilim tahsil eden bireylerin yaygınlaştırılmasıyla giderilebilir. $\mathrm{Bu}$ konuda özellikle din öğretimine önemli görevler düşmektedir.

Din öğretiminde kültürün korunmasını amaç edinen kültür muhafızı

52 Günay, “Çağdaş Türkiye'de Din, Toplum, Kültür, Gelenek ve Değişme”, 3.

${ }^{53}$ Hanafi, "İslam ve Batılılaşma”, 497.

${ }^{54}$ Osman Eskicioğlu, "Batılılaşma Anlamındaki Çağdaşlașmanın İslam Hukuku Açısından Değerlendirilmesi”, Türkiye’nin Çağdaşlaşma Problemi ve İslam, ed. Mehmet Demirci (Ankara: Türkiye Diyanet Vakfi Yayınları, 2000), 51.

55 Kamil Şahin, "Kültürel Yozlașmaya Neden Olan Bir Unsur Olarak Televizyon", Kırıkkale Üniversitesi Sosyal Bilimler Dergisi 1/1 (2011), 273; Çelik - Babaoğlan, “Üniversite Öğrencilerinin Yabancılaşma Düzeyi", 422. 
bir neslin yetiştirilmesi için dinin gücünden faydalanılabilir. Zira nitelikli bir din öğretimi aracılığıyla bireyin davranışlarında otokontrol kazanması sağlanabilir ve kültürel değerler toplumun bireylerine benimsetilebilir. Böylece din öğretimi toplumda sosyal düzenin, kültürel değerlerin korunması için etkin bir rol oynayabilir. Çünkü dinin sosyal ve kültürel değişimi sınırlandırma, engelleme ya da değişim olumlu yöndeyse destekleme potansiyeli bulunmaktadır. ${ }^{56}$ Bundan ötürü profesyonel bir din öğretiminin kültürel yabancılaşma ve yozlaşmayı yavaşlatabileceği söylenebilir. O halde din öğretiminde yeni neslin zihinlerine ve vicdanına kültürü korumanın millî ve ahlakî bir görev olduğu bilincinin yerleștirilmesi hedeflenmelidir.

\subsubsection{Kültürüi Geliştirme Bilinci Kazandırma Amacı}

Hiçbir toplum durağan bir yapıya sahip olamaz. Doğası gereği bütün toplumlar için değişim kaçınılmazdır. Yani herhangi bir toplumda değişimin yokluğundan ziyade hızındaki farklılıktan bahsetmek daha doğrudur. Sosyal değişme adı verilen bu süreç, kültürleri de derinden etkiler. Nitekim bu süreçte toplumca benimsenen normların, değerlerin, örf ve adetlerin bir bölümü yapı değiştirirken bir bölümü tamamen ortadan kalkabilir. ${ }^{57}$ Değişim kaçınılmaz olduğu için değişime karşı direnmek doğru değildir. Burada esasen önemli olan husus değişimin gerileme mi yoksa gelişme mi olarak nitelendirilebileceğidir. Bu durum kültürün çeşitli unsurları açısından farklı şekillerde değerlendirilebilir. Çünkü sosyal değişim, kültürel unsurların bir kısmını olumlu anlamda, bir kısmını da olumsuz anlamda etkileyebilir. Bu bakımdan düşünüldüğünde kültürün maddî unsurlarıyla manevî unsurları arasında gelişme ve ilerleme açısından her zaman bir uyum ve dengeden bahsetmek güçtür. Çünkü aynı toplum içerisinde maddî sahada ilerleme meydana gelirken manevî sahada bir gerileme baş gösterebilir ki buna toplumsal çözülme adı verilir.

Dünya çapında son yıllarda meydana gelen değişime bakıldığında birçok toplumun odak noktasının teknolojik anlamda ilerleme olduğu izlenimi ortaya çıkmakta, maddî alandaki gelişmelerin topyekûn anlamda bir kalkınmaya vesile olacağı düşünülebilmektedir. Oysaki herhangi bir toplumda sadece maddeye dayalı bir yaşam söz konusu olamayacağı için gelişmenin yalnızca maddî olanla, ilerlemenin gözle görülebilir, elle tutulabilir olanla aynîleştirilmesi büyük bir hatadır. ${ }^{58}$ Çünkü kültürel anlamda

\footnotetext{
${ }^{56}$ Meredith B. McGuire, Religion: The Social Context (California: Wads Wordth Publishing Company, 1987), 196; Günay, "Çağdaş Türkiye'de Din, Toplum, Kültür, Gelenek ve Değişme”, 5.

57 Arslantürk, "Sorumluluk Şuurunun Sosyo-Kültürel Arkaplanı", 354.

${ }^{58}$ Muhammed Enes Topgül, "Kutsalsı Yollar: Dünyevileşme Örneği”, Eskiyeni 14 (Eylül 2009),
} 
dengeli ve sağllklı bir gelişme ancak madde-mana bütünlüğünün gözetilmesiyle mümkündür. Nitekim değerlerden yoksun, bireyleri doğruyu ve iyiyi yapmaya yönelten vicdan denilen güdüden bîhaber olan toplumların teknolojiye hâkim olması kendileri de dahil olmak üzere insanlık için büyük bir tehdit olarak görülebilir.

Bir ülkenin kalkınması ve uyumlu bir toplumsal yapıya kavuşması için bilgili ve becerili insanların yetiştirilmesi kadar sahip olduğu bilgi ve becerileri vatanının, milletinin, insanlığın yararına kullanma bilinci taşıyan millî ve insanî duygusu kuvvetli nesillerin yetiştirilmesi de şarttır. Bundan ötürü teknolojinin topluma ve insanlığa yararlı olabilmesi için millî ve insanî değerlerle yoğrulması gerekir. ${ }^{59} \mathrm{Bu}$ bilincin bireylerin zihnine yerleşerek davranışlarına yansıması nitelikli bir eğitim yoluyla sağlanabilir. Özellikle profesyonel bir din öğretimi, bu amaca erişilmesi için önemli bir katkı sağlayabilir. Bunun için din öğretimi faaliyetleri yürütülürken İslâm medeniyetinin birikiminden yararlanarak kültürel mirasa katkı sağlayacak, mevcut değerlerin güçlenmesi ve zenginleşmesi için sorumluluk alacak, ihtiyaca göre sanal yaşam alanı gibi daha önce var olmayan ortamlarda benimsenmek üzere yeni değerler üretebilecek niteliklere sahip bir neslin yetiştirilmesi temel amaç olarak kabul edilmeli ve bunun gereği yerine getirilmelidir.

Toplumun ve kendisine özgü kültürünün tarihe karışmamasi için yeni değer üretebilen bireylerin yetiştirilmesi ${ }^{60}$ ve onların yaşadığı toplumun kültürünü ileri seviyelere taşımaya yönlendirilmesi sosyal bir ihtiyaçtır. İşte bu sebepledir ki din öğretiminde toplum içindeki ve dışındaki kültürlerle etkileşime girebilme kapasitesini ifade eden kültürel zekânın ${ }^{61}$ geliştirilmesine yönelik strateji, yöntem ve tekniklere başvurulması önem taşımaktadır. Bu bağlamda derslerde öğrenciler kültür üzerine düşündürülebilir, onların karşılaştırma, çıkarımda bulunma, problem çözme gibi üst düzey zihinsel becerilerine hitap edilerek mevcut kültürü incelemeleri, eleştirmeleri ve geliştirmeleri için rehberlik edilebilir. Zira kültürel miras, cansız, kapalı, durağan bir yığın ya da bireyin kayıtsız şartsız uymak zorunda olduğu bir olgu olarak değil, üzerinde çalışılarak anlaşılmas1, problem çözmede kullanılması, geliştirilmesi gereken bir unsur olarak görülmelidir. ${ }^{62}$

52

59 Çelikkaya, “Öğretmenlerin Kültürleme ve Sosyalleștirme Etkileri Üzerine Bir Araștırma”, 45.

${ }^{60}$ Osman Eğri, "Eğitimin Genel Amaçları Açısından Din Kültürü ve Ahlak Bilgisi Dersleri”, Ankara Üniversitesi İlahiyat Fakültesi Dergisi 44/1 (2003), 274.

${ }^{61}$ Mustafa İlhan - Bayram Çetin, "Kültürel Zekâ Ölçeği'nin Türkçe Formunun Geçerlik ve Güvenirlik Çalışması”, Hacettepe Üniversitesi Eğitim Fakültesi Dergisi 29/2 (Nisan 2014), 95.

62 Selçuk, "Teorik ve Pratik Açmazlarılla Kültürel Miras Öğretimini Sorgulayan Bir Deneme", 
Din öğretimi, öğrencilerin kültürel unsurlara körü körüne bağlanmalarının da önüne geçmelidir. Çünkü kültürel mirasın her zaman ve her koşulda hatasız ve rasyonel olması beklenemez. Toplumsal normların bazıları bilimle çatışarak gelişime engel olabilir. ${ }^{63}$ Böyle bir durumda yanlış olanların ayıklanarak bertaraf edilmesi ve olumlu olanların alınarak geliştirilmesi toplumun sorumluluğudur. Bu sorumluluk bilinci başta din öğretimi olmak üzere ancak eğitim yoluyla onlara kazandırılabilir. Öyleyse din öğretiminde sosyal yaşamla bağ kurulmalı, öğrencilerin kendi kültürel kaynaklarının gücü hakkında farkındalık kazanarak, ahlakî ve insanî olana yönelerek kültürel mirasa katkı sağlamaları desteklenmelidir.

\section{Sonuç}

Kültürel yabancılaşma ve yozlaşma milletlerin toplumsal varlığını devam ettirmesini engelleyen, evrensel boyutlara ulaşan bir sorundur. Öyle görülüyor ki bu gidişata bir şekilde dur denilmezse toplumsal çöküş bir salgın hastalık gibi tüm dünyayı saracak ve insanlığı müşkil bir duruma sokacaktır. Hal böyle iken insanlığın bu girdabın içinden kurtuluşu için eli kolu bağlı bir şekilde mucize beklemesi, kurtuluşu salt maddî gelişimde araması makul bir çözüm yolu değildir. Bu sorunla bütün toplumların kendisine özgü yöntemlerle millet olarak mücadele etmesi, öz kültürlerine sahip çıkması gerekmektedir.

Kültürel yabancılaşma ve yozlaşma tehdidiyle mücadele etme meselesi Türkiye özelinde ele alındığında ülkede bu amaçla eğitim öğretim faaliyetlerinden yararlanıldığı söylenebilir. Nitekim ülkenin eğitim sisteminin genel amaçları incelendiğinde kültürel aidiyet ve sorumluluk bilinci kazandırmayla doğrudan ilişkilendirilebilecek hedefler göze çarpmaktadır. Lâkin söz konusu amaçların pratiğe istenen oranda yansıdığını söylemek oldukça güçtür. Bunun nedeni meseleyle ilgili paydaşların söz konusu hedefler hakkında yeterince farkındalık kazanmaması olabilir.

Türk kültürünün teşekkülünde dinî inanç ve değerlerin yadsınamaz bir rolünün bulunmasından dolayı din öğretimiyle ilgili paydaşların bu hususta farkındalık kazanarak sorumluluk üstlenmesi ayrı bir önem taşımaktadır. Ancak küreselleşmeyle birlikte çok kültürlü yaşam alanlarının genişlemesinden kaynaklı olsa gerek ki din eğitimi alanıyla ilgili literatüre bakıldığında kültürlerarası öğretimle ilgili çalışmalar alan yazında daha fazla yer işgal ediyor gibi görülmektedir. Oysaki gelişen ve değişen şartlar gereği farklı kültürlere mensup bireylerin varlığı elbette görmez-

258.

${ }^{63}$ Arslantürk, "Sorumluluk Şuurunun Sosyo-Kültürel Arkaplanı”, 330. 
den gelinemez. Ancak çok kültürlü eğitimin ölçüsüzce işletilmesiyle toplumun öz kültürü de feda edilemez. Öte yandan öncelikle kültürel yetkinlik kazandıramayan bir öğretim aracilığıyla kültürlerarası yetkinlik kazandırma amacına erişilmesi de beklenemez. Zira kendi kültürünü bile yeterli ölçüde tanıyamayan bir kişinin başka kültürlerle empati, saygı ve hoşgörü çerçevesinde sağlıklı bir etkileşimde bulunabilmesi oldukça zordur. Bu değerlendirmelerden sonra araştırmanın sonuç ve önerileri şu şekilde ifade edilebilir:

- Öğretimde toplumsal değerlerin kazandırılmasına öncelik verilmeyerek eğitim sisteminin akademik başarı üzerine odaklanan bir yapı üzerine kurulması, kültür ağacının kökünün kurutulmasına benzetilebilir. Dinin kültürün teşekkülündeki tesiri dolayısıyla din öğretimi aracıllğıyla millî kültür ağacının kökleri beslenebilir ve kuruyan, bozulan, işlevselliğini yitirmiş dalları budanarak toplumun ileri seviyelere taşınması için önemli katkı sağlanabilir.

- Eğitimde bireylere kültürel yetkinlik kazandırılması uzmanlık gerektiren bir iştir. Üstelik halihazırdaki sosyal değişmenin hızından dolayı söz konusu yetkinliğin kazanılması için her geçen gün yeni bilgi ve becerilere ihtiyaç duyulabilmektedir. Bu nedenle bireyin gelecekte ihtiyaç duyacağ bilgi ve becerileri uzman desteğine gerek duymadan kendi başına kazanabilecek bir şekilde yetiștirilmesi gerekmektedir. Bunun için de din öğretiminde kültürel amaçların kazandırılmasını hedefleyen konuların işlenmesi sürecinde problem çözme becerisinin kazandırılmasına yönelik etkinliklere bolca yer verilmelidir.

- Kültürün korunması için toplumun kendi içine kapanarak dünya çapında meydana gelen değişime ve gelişime göz yumması doğru değildir. Bunun yerine diğer kültürler de yakından takip edilmeli, onların yapısındaki iyi özelliklerden faydalanılarak ya da kültürel anlamda varlığını devam ettiremeyen, başka kültürlerin hegemonyası altında yaşamlarını sürdüren toplumlardan ibret alınarak kültürün geliștirilmesi ve zenginleştirilmesi için çaba gösterilmelidir. Bu nedenle din öğretimin kültürel amaçları güncellenirken bu husus gözden kaçırılmamalıdır.

- Din öğretiminde öğrencilere kültürel yetkinlik kazandırılmaya çalış1lırken toplumun geçmişiyle, Kur'an ve sünnetle olan bağ koparılmamalıdır. Çünkü Türk milletinin ve İslâm medeniyetinin zengin kültürel mirasında modern toplumların kültürel gelişimine rehberlik edecek ilham verici köklü değerler mevcuttur. Öte yandan Türkiye'deki din çeşitliliğinden kaynaklanan çok kültürlülüğün boyutları batı toplumlarındaki gibi değildir. Şayet öyle olsa bile öğretim faaliyetlerinde Türk-İslâm toplumunun asırlar boyu Anadolu üzerinde süregelen ortak yaşama kültürü 
örnek alınarak temelinde akıl, bilim ve değerlerin bulunduğu bir kültürün teşekkülü için katkı sağlanabilir.

- Son olarak örgün öğretimin baş aktörünün öğretmenler olduğu söylenebilir. Öğretmenler öğrencilerin kültürel anlamda yetkinlik kazanmaları hususunda da mesuldür. Onlar birçok öğrencinin düşünce ve davranışlarını etkileyerek onlar için rol model olabilmektedir. Bu nedenle öğretmen yetiştiren kurumlar toplumun kültürünü temsil edebilecek bireyler yetiştirme konusunda özen göstermelidir.

\section{Kaynakça}

Akkurt, Suna (ed.). Anadolu Imam Hatip Lisesi Temel Dini Bilgiler Ders Kitabı. Ankara: MEB Yayınları, 2019.

Al-Attas, Syed Muhammad Naquib. "İlmin Yozlaşması ve Fikri Çözünme Meselesi”. çev. Bülent Nuri. Journal of Islamic Research 7/3-4 (1994), 215-221.

Arslantürk, Zeki. "Sorumluluk Şuurunun Sosyo-Kültürel Arkaplanı”. Kur'anKerim'de Mes'ûliyet (Kaynağı, Stnırları, Sonuçları). ed. Bedreddin Çetiner. 327360. İstanbul, 2006.

Bulut, Ramazan. "Okulda Din Öğretiminin Toplumsal Temeli ve İşlevleri”. Sosyal Bilimler Dergisi 7/1 (2011), 20-37. https://doi.org/10.12780/UUSBD80

Cebeci, Suat. "Milli Kimlik Bağlamında Din - Kültür İlişkisi”. Akademik İncelemeler Dergisi 3/2 (Ağustos 2014), 1-11.

Creswell, John W. Araştırma Deseni: Nitel, Nicel ve Karma Yöntem Yaklaşımları. çev. ed. Selçuk Beşir Demir. Ankara: Eğiten Kitap Yayınları, 3. Baskı., 2017.

Çalgan, Mehmet Ali. “íslâm'da Toplumsal Sorumluluk Şuuru ve Günümüzde Toplum İçin Önemi”. Pamukkale Üniversitesi İlahiyat Fakültesi Dergisi 3 (Mart 2015), 26-43.

Çapçıŏlu, İhsan. “Küreselleşme, Kültür ve Din”. AÜFD XLIX/II (2008), 153-183.

Çelik, Ejder - Babaoğlan, Emine. "Üniversite Öğrencilerinin Yabancılaşma Düzeyi”. Ahi Evran Üniversitesi Kırşehir Eğitim Fakültesi Dergisi 18/1 (Nisan 2017), 405-427.

Çelikkaya, Hasan. "Öğretmenlerin Kültürleme ve Sosyalleştirme Etkileri Üzerine Bir Araştırma”. Marmara Üniversitesi Eğitim Bilimleri Dergisi 26/26 (2007), 2747.

Diler, Ramazan. Gazetelerde Din Dersi Tartışmaları. Ankara: İlahiyat, 1. Baskı., 2020. Eğri, Osman. "Eğitimin Genel Amaçları Açısından Din Kültürü ve Ahlak Bilgisi Dersleri”. Ankara Üniversitesi İlahiyat Fakültesi Dergisi 44/1 (2003), 271-291.

Engebretson, Kathleen. "Learning about and learning from religion. The pedagogical theory of Michael Grimmitt". International Handbook of the Religious, Moral and Spiritual Dimensions in Education. ed. Marian de Souza vd. 667-678. Dordrecht: Springer, 2006.

Eskicioğlu, Osman. "Batılılaşma Anlamındaki Çağdaşlaşmanın İslam Hukuku 
Açısından Değerlendirilmesi”. Türkiye'nin Çağdaşlaşma Problemi ve İslam. ed. Mehmet Demirci. 51-55. Ankara: Türkiye Diyanet Vakfi Yayınları, 2000.

Giddens, Anthony. Modernliğin Sonuçları. çev. Ersin Kuşdil. İstanbul: Ayrıntı Yayınları, 1998.

Günay, Ünver. “Çağdaş Türkiye'de Din, Toplum, Kültür, Gelenek ve Değişme”. Çukurova Üniversitesi İlahiyat Fakültesi Dergisi 1/2 (Haziran 2001), 1-38.

Günay, Ünver. “İktisadi Ahlak ve Din”. Atatürk Üniversitesi İlahiyat Fakültesi Dergisi 7 (2006), 109-128.

Güncel Türkçe Sözlük. Erişim 10 Nisan 2020. https://sozluk.gov.tr/

Hanafi, Hassan. “İslam ve Batılılaşma”. çev. Yaşar Gedikli. On Dokuz Mayıs Üniversitesi İlahiyat Fakültesi Dergisi 10 (1998), 491-499.

İlhan, Mustafa - Çetin, Bayram. "Kültürel Zekâ Ölçeği'nin Türkçe Formunun Geçerlik ve Güvenirlik Çalışması”. Hacettepe Üniversitesi Eğitim Fakültesi Dergisi 29/2 (Nisan 2014), 94-114.

Jary, David - Jary, Julia. Dictionary of Sociology. Glasgow: Harper Collins Publishers, 2nd edition., 1995.

Karataş, Veli (ed.). Ortaöğretim Din Kültürü ve Ahlak Bilgisi 9. SınıfDers Kitabı. Ankara: MEB Yayınları, 2. Basım, 2019.

Macit, Sadullah. Ortaokul ve İmam Hatip Ortaokulu Din Kültürü ve Ahlak Bilgisi Ders Kitabı 7. Ankara: FCM Yayınc1lı, 2020.

Mark E. Mendenhall vd. Global Management. Oxford, UK: Blackwell Pub., 1995.

Maslow, Abraham Harold. Motivation and Personality. New York: Harper and Row, 2nd Edition., 1970.

McGuire, Meredith B. Religion: The Social Context. California: Wads Wordth Publishing Company, 2. Edition., 1987.

MEB. Din Kültürü ve Ahlak Bilgisi Dersi Öğretim Programı (İlkokul 4 ve Ortaokul 5, 6, 7 ve 8. Sinflar). Ankara: MEB Yayınları, 2018.

METK, Milli Eğitim Temel Kanunu. Resmî Gazete 14574 (2 Haziran 1973). Erişim 3 Nisan 2020. https://www.mevzuat.gov.tr/MevzuatMetin/1.5.1739.pdf

Namlı, Tuncer. "Kuran ve Dünyevileşme ya da Bir Dünya Görüşü Kırılması”. Eskiyeni 13 (Haziran 2009), 40-53.

Okumuş, Ejder. “Toplum Bağlamında Din-Kültür Etkileşimi”. Electronic Turkish Studies 11/7 (2016), 269-292.

Okumuşlar, Muhiddin - Bilecik, Sümeyra. "Kültürel Din Pedagojisi”. Cumhuriyet İlahiyat Dergisi 23/3 (Aralık 2019), 1279-1292. https://doi.org/10.18505/ cuid.589992

Özden, Haci Ömer. "Bir Ahlâk Problemi Olarak Yabancılaşma ve Yahya Kemal”. İlahiyat Akademi 2/3 (Eylül 2016), 101-112.

Özen, Yener. Sorumluluk Eğitimi. Ankara: Vize Basın Yayın, 2015.

Perşembe, Erkan. "Küreselleşme Kültürü ve Eğitimin İşlevi”. Ondokuz Mayıs Üniversitesi İlahiyat Fakültesi Dergisi 20/20-21 (Mart 2005), 101-112. https://doi. org/10.17120/omuifd.09839

Selçuk, Mualla. “Teorik ve Pratik Açmazlarıyla Kültürel Miras Öğretimini Sor- 
gulayan Bir Deneme". Ankara Üniversitesi İlahiyat Fakültesi Dergisi 39/2 (1999), 255-264. https://doi.org/10.1501/Ilhfak_0000001341

Şahin, Kamil. "Kültürel Yozlaşmaya Neden Olan Bir Unsur Olarak Televizyon”. Kırıkkale Üniversitesi Sosyal Bilimler Dergisi 1/1 (2011), 243-277.

Taylor, Edward B. The Origins of Culture and Religion in Primitive Culture. New York: Harper\&Brothers, 1958.

Topçu, Nurettin. Türkiye’nin Maarif Davası. İstanbul: Dergah Yayınları, 8. Baskı., 2012.

Topgül, Muhammed Enes. “Kutsalsız Yollar: Dünyevileşme Örneği”. Eskiyeni 14 (Eylül 2009), 52-64.

Tuncer, Murat vd. "Sosyal Araştırmalardaki Ölçek Bulgularına Örneklem Etkisinin Araştırılması". Electronic Journal of Education Sciences 6/11 (2017), 1-10.

Turan, İbrahim. "Gençlik Döneminde Görülen Ahlaki Sorunlar Karşısında Din Kültürü ve Ahlak Bilgisi Dersinin Yeri”. Atatürk Üniversitesi İlahiyat Fakültesi Dergisi 40 (2013), 271-293.

Twenge, Jean M. Ben Nesli. çev. Esra Öztürk. İstanbul: Kaknüs Yayın, 4. Baskı., 2013.

Uygur, Özlem - Doğan, Süleyman. "Ahlaki Çöküşe Bir Çözüm Önerisi Olarak Türk İslam Ahlakı". IX. Uluslararası Dİn Görevlileri Sempozyumu Bildirileri. ed. Mustafa Sürün. 195-202. İstanbul: YECVA, 2019.

Wach, Joachim. Din Sosyolojisi. çev. Ünver Günay. İstanbul: Marmara Üniversitesi İlahiyat Fakültesi Vakfı Yayınları, 1995.

Yılmaz, Hüseyin. Din Eğitimi ve Sosyal Barış. İstanbul: İnsan Yayınları, 2003.

Yiğit, Yasin - Koca, Hüseyin Kasım. "Din Öğretiminde Kültürel Aidiyet ve Sorumluluk Bilinci Kazanma Amacına Erişim Düzeyi Ölçeği: Geçerlik Güvenilirlik Çalışması”. Bingöl Üniversitesi İlahiyat Fakültesi Dergisi 14 (Aralık 2019), 112-127. https://doi.org/10.34085/buifd.634777 